\author{
M.S. Sagyndykova ${ }^{1}$, A.A. Imanbayeva ${ }^{1}$, M. Yu. Ishmuratova*1, ${ }^{1,}$, G.G. Gassanova ${ }^{1}$ \\ ${ }^{1}$ Mangyshlak Experimental Botanical Garden, Aktau, Kazakhstan; \\ ${ }^{2}$ Karagandy University of the name of academician E.A. Buketov, Karaganda, Kazakhstan \\ *Corresponding author: margarita.ishmur@mail.ru
}

\title{
Analysis of flora of the medicinal plants of the Atyrau region
}

\begin{abstract}
Medicinal plants are important sources of biologically active substances and phytopreparations for the prevention and treatment of diseases. In Kazakhstan, the regions of the Western Kazakhstan remain poorly studied in relation to wild medicinal plants. The purpose of the present study was to analyze the species composition of medicinal plants of the flora of the Atyrau region and their ranking by life forms, ecological groups, the degree of distribution and possibility of application in medical practice. Based on the analysis of literary sources and the results of own field studies in the Atyrau region, 177 species of medicinal plants belonging to 118 genera and 46 families are identified. The largest number of species of medicinal plants is noted in Asteraceae, Lamiaceae, Brassicaceae, Rosaceae, Chenopodiaceae, Fabaceae and Polygonaceae families. According to the degree of distribution, 4 groups of plants are identified: i) widespread plants, but growing sporadically, not forming thickets (128 species); ii) rare and endangered plants, not to be harvested for raw materials (11 species); iii) plants, forming small thickets (23 taxa); iv) plants, forming significant thickets suitable for industrial harvesting (15 taxa). Among the medicinal plants of the Atyrau region, 6 ecological groups were identified in relation to humidification conditions: hydrophytes, hygrophytes, mesophytes, mesoxerophytes, xerosesophytes and xerophytes. 8 groups of life forms are defined. The largest number of species is concentrated in the group of perennial herbaceous plants - 105 taxa. 128 taxa are allocated for use in folk medicine, 49 species - in official medicine. 12 pharmaceutical-therapeutic groups of plants for treatment of diseases of various etiologies are identified.
\end{abstract}

Keywords: medicinal plant, Atyrau region, systematic, life forms, ecological group, spreading, pharmacological properties, using in folk and officinal medicine.

\section{Introduction}

The development of modern industries and the rapid growth of the human population in the next $30-50$ years present for scientists the task of finding new renewable resources: food sources, bio fuels, medicinal preparations, cosmetics and hygiene products. These needs will undoubtedly lead to increased interest in vegetative resources, which are a renewable for production of the raw materials. The World Health Organization notes in recent decades an increase in the use of herbal preparations and an increase in the proportion of medicinal plants by the population of the earth, which has become the basis for the development of an appropriate strategy [1].

In many countries, it is recommended to create a base for active management of traditional medicine, recognition of its role, strengthening the database, and creating mechanisms for the regulation of preparations of plant and animal origin.

Biologically active compounds released from medicinal plants, as well as their individual components from ancient times, have been used by humans as medicinal, antiseptic, perfumery and protective agents (repellents, attractants and others) [2-8]. Present days, the production of components based on medicinal plants is widely developed in many countries. Thus, $65 \%$ of the total production of phytopreparations is accounted for by developing countries, $35 \%$ - by industrialized states [9]. Republic of Kazakhstan has rich raw material potential of wild and cultivated useful plants [10], but own phytopreparations are presented insignificantly, as well as production of medicinal raw materials.

Kazakhstan independence sets the State the task of creating and developing its own industries, including medical and pharmaceutical. Pharmaceutical enterprises in Kazakhstan provide domestic needs by no more than 5-7\%, the remaining share of medicines is imported from abroad. However, the production of medicinal products, especially of plant origin, should be based on a stable raw material base, which is possible with the use of new types of medicinal products with their complex study, sustainable use and protection [11].

The purpose of this study is to analyze the species composition of medicinal plants of the flora of the Atyrau region and their ranking by life forms, ecological groups, degree of distribution and possibility of application in medical practice. 


\section{Materials and methods}

The Atyrau region is located in the extremely western part of Kazakhstan within the coordinates E $47^{\circ} 05^{\prime}-56^{\circ} 45^{\prime}$ and $\mathrm{N} 41^{\circ} 20^{\prime}-49^{\circ} 15^{\prime}$, extending from west to east to $720 \mathrm{~km}$ and from south to north to $880 \mathrm{~km}$. In the west it borders with the Astrakhan region of the Russian Federation, in the north - with the Western-Kazakhstan region, in the northeast - with the Aktobe regions, in the southeast — with the Karakalpak autonomy, in the south - Turkmenistan, from the south-west it is washed by the Caspian Sea [12]. The territory of the region is 118.0 thousand $\mathrm{km}^{2}$.

According to the geological structure, surface structure and soil-botanical conditions, the territory of the region is quite clearly divided into the following large geo-morphological areas: the Caspian lowland, the Ural plateau and the Ustyurt plateau. The climate is sharply continental, arid type. Summer is hot and durable; winter is moderately frosty and short.

The objects of the study are wild natural populations of medicinal plants of the flora of the Atyrau region. The identification of the species composition of medicinal plants is carried out according to literary data [16-20], analysis of herbarium material and materials of previous field surveys on various floristic areas (Caspian, Embinsky, Bukeev). The names of the plants are given in accordance with the reference book of S.K. Czerepanov [21].

All separated species are ranked according to the following indicators: 1) by systematic groups [22]; 2) by life forms [23]; 3) by ecological groups [24]; 4) by degree of spreading; 5) by pharmaceuticaltherapeutic action [25-28] and 6) using in official and folk medicine [10].

\section{Results and discussion}

As the results of the analysis of literary data and own field surveys, 177 species of medicinal plants from 118 genera and 46 families were identified in the Atyrau region (Table 1).

T a b l e 1

Taxonomic composition of the medicinal plants of the Atyrau region's flora

\begin{tabular}{|c|c|c|c|c|c|}
\hline Family & Genus & Species & Family & Genus & Species \\
\hline Equisetaceae & 1 & 3 & Salicaceae & 2 & 4 \\
\hline Cupressaceae & 1 & 1 & Betulaceae & 1 & 2 \\
\hline Ephedraceae & 1 & 1 & Cannabaceae & 1 & 1 \\
\hline Alismataceae & 1 & 1 & Urticaceae & 1 & 1 \\
\hline Poaceae & 1 & 1 & Polygonaceae & 4 & 5 \\
\hline Araceae & 1 & 1 & Chenopodiaceae & 3 & 7 \\
\hline Lemnaceae & 1 & 1 & Amaranthaceae & 1 & 2 \\
\hline Liliaceae & 2 & 3 & Portulacaceae & 1 & 1 \\
\hline Asparagaceae & 1 & 1 & Caryophyllaceae & 1 & 1 \\
\hline Iridaceae & 1 & 1 & Nymphaeaceae & 1 & 1 \\
\hline Ranunculaceae & 3 & 3 & Peganaceae & 1 & 1 \\
\hline Papaveraceae & 1 & 1 & Nitrariaceae & 1 & 2 \\
\hline Fumariaceae & 1 & 1 & Polygalaceae & 1 & 1 \\
\hline Brassicaceae & 10 & 11 & Rhamnaceae & 2 & 2 \\
\hline Rosaceae & 9 & 10 & Malvaceae & 3 & 3 \\
\hline Fabaceae & 6 & 8 & Hypericaceae & 1 & 1 \\
\hline Linaceae & 1 & 1 & Elaeagnaceae & 1 & 1 \\
\hline Apiaceae & 4 & 4 & Onagraceae & 2 & 2 \\
\hline Limoniaceae & 2 & 3 & Orobanchaceae & 1 & 1 \\
\hline Gentianaceae & 1 & 1 & Plantaginaceae & 1 & 6 \\
\hline Boraginaceae & 3 & 3 & Dipsacaceae & 2 & 3 \\
\hline Lamiaceae & 13 & 19 & Asteraceae & 16 & 42 \\
\hline \multirow[t]{2}{*}{ Solanaceae } & 2 & 4 & Scrophulariaceae & 3 & 4 \\
\hline & & & Total: 46 & 118 & 177 \\
\hline
\end{tabular}

The largest number of species of medicinal plants is noted in Asteraceae, Lamiaceae, Brassicaceae, Rosaceae, Chenopodiaceae, Fabaceae and Polygonaceae families. These 6 leading families contain 57 genera or $48.3 \%$ of the total number of genera, as well as, 97 species or $54.7 \%$ of the total number of medicinal plant species. 
On the basis of the flora conception, the identified species of medicinal plants are ranked by the degree of prevalence in natural populations. So, all medicinal plants in the territory of the Atyrau region are separated on 4 groups:

i) Widespread, but growing sporadically, not forming thickets (128 species). Among them are species such as: Alisma plantago-aquatica, Asparagus officinalis, Populus tremula, Polygonum aviculare, Gypsophila paniculata, Thalictrum collinum, Thlaspi arvensis and others;

ii) Rare and endangered species, that cannot be harvested for raw materials (11 species), including Juniperus sabina, Acorus calamnus, Nuphar luteum, Pulsatilla patens, Fritillaria meleagroides, F.ruthenica, Adonis vernalis, Amygdalus nana and others;

iii) Species, forming small thickets (23 species): Sanguisorba officinalis, Ephedra distachya, Iris tenuifolia, Syrenia sessiliflora, Helichrysum arenarium, Rubus caesius, Melilotus officinalis, Peganum harmala, Polygala comosa and others;

iv) Species with significant thickets, suitable for industrial harvesting (15 species). They are: Limonium gmelinii, Rheum tataricum, Althaea officinalis, Anabasis salsa, Artemisia terrae-albae, Salvia stepposa, Scabiosa isetensis, Achillea nobilis and others.

Medicinal plants are ranked according to life forms and ecological groups. In the Atyrau region, medicinal plants belong to 6 ecological groups in relation to humidification conditions: hydrophytes, hygrophytes, mesophytes, meso-xerophytes, xero-xerophytes and xerophytes (Fig. 1).

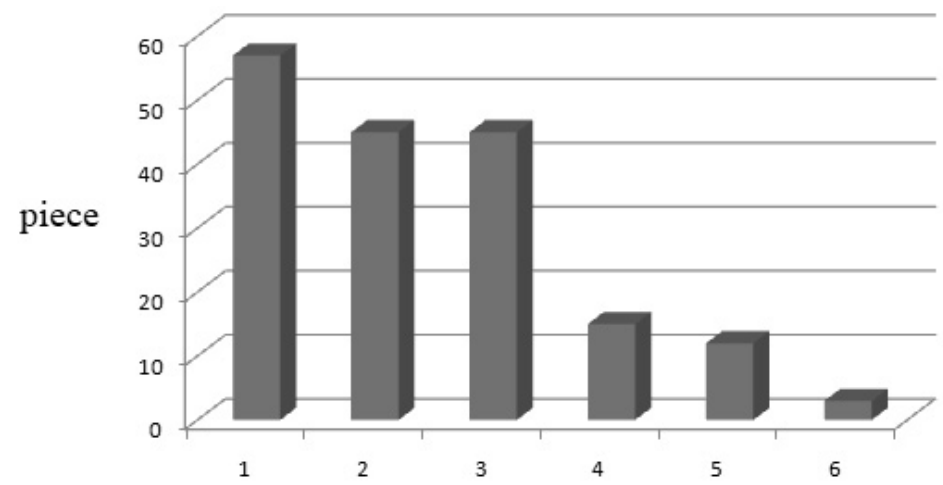

1 -xerophytes; 2 - mesophytes; 3 - meso-xerophytes; 4 - hygrophytes; 5 - xero-mesophytes; 6 - hydrophytes

Figure 1. Distribution of medicinal plants of the flora of the Atyrau region by ecological groups

The largest number of species was noted among the xerophyte group -57 taxa. The group of mesophytes and meso-xerophytes is occupied the 2nd position (by 45 taxa). In third place are hygrophytes (15 species), in fourth - xeromesophytes with 12 taxa. The last place is occupied by a group of hydrophytes with 3 species.

There are 8 types of life forms among medicinal plants (Fig. 2).

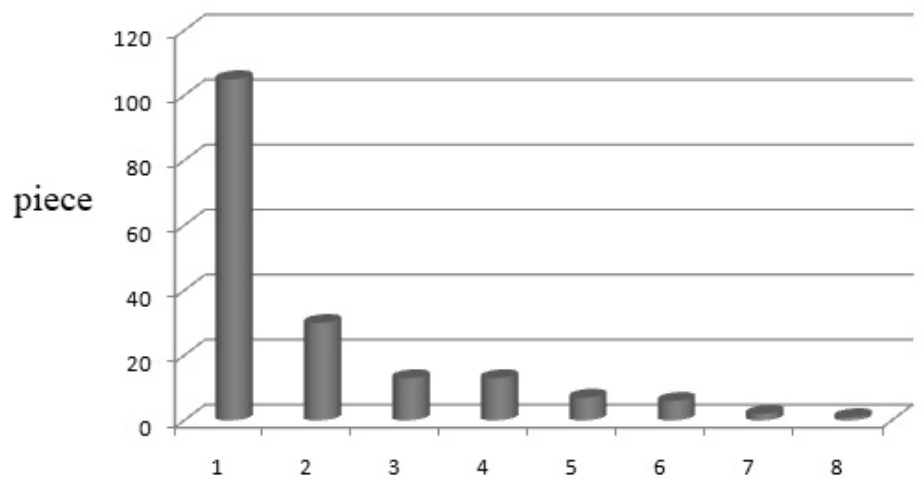

1 - herbaceous perennials; 2 - herbaceous annuals; 3 - herbaceous biennials; 4 - shrubs; 5 - trees; 6 - semi-shrubs; 7 - low shrubs; 8 - low semi-shrubs

Figure 2. Distribution of medicinal plants of flora of Atyrau region by life forms 
The largest number of species is concentrated in the group of perennial herbaceous plants - 105 taxa, in second place - herbaceous annual plants - 30 species, in third - herbaceous biennial plants and shrubs (by 13 species), in fourth - trees ( 7 species), in fifth - semi-shrubs (6 species). The last positions are occupied by a group of low shrubs ( 2 species) and low semi-shrubs (1 taxon).

The dominant number of species belongs to group used in folk medicine (128 taxa); 49 species are used in official medicine. Analysis of application of identified species in medicine on the basis of pharmaceuticaltherapeutic action is carried out. 12 groups are separated (Table 2).

Ta b le 2

Distribution of medicinal plants of the flora of the Atyrau region by pharmaceutical-therapeutic properties

\begin{tabular}{|c|l|c|c|}
\hline № & \multicolumn{1}{|c|}{ Pharmaceutical-therapeutic group } & $\begin{array}{c}\text { Number } \\
\text { of species, piece }\end{array}$ & $\begin{array}{c}\text { \% from total } \\
\text { number of species }\end{array}$ \\
\hline 1 & For the treatment of the gastrointestinal tract & 92 & 51.9 \\
\hline 2 & For the treatment of diseases of the oral cavity & 29 & 16.4 \\
\hline 3 & For the treatment of kidneys and urinary tract & 52 & 29.3 \\
\hline 4 & For the treatment of diseases of the respiratory system & 70 & 39.6 \\
\hline 5 & Used as antipyretic and anti-inflammatory agents & 73 & 41.2 \\
\hline 6 & For the treatment of the cardiovascular and nervous system & 56 & 31.6 \\
\hline 7 & As anti-parasite agents & 29 & 16.4 \\
\hline 8 & For the treatment of gynaecological diseases & 21 & 11.9 \\
\hline 9 & As antidiabetic agents & 15 & 8.5 \\
\hline 10 & Wound healing and painkillers & 29 & 16.4 \\
\hline 11 & For the treatment of skin diseases & 28 & 15.8 \\
\hline 12 & Having other properties & 131 & 74.0 \\
\hline
\end{tabular}

The largest number of species has other types of activity - 131 taxa (or $74.0 \%$ ). Among the identified pharmaceutical therapeutic properties, the maximum number of species can be used to treat diseases of the gastrointestinal tract - 92 species (or $51.9 \%$ ). 73 species (or $41.2 \%$ ), can be used as antipyretic and antiinflammatory agents. A smaller number of species (70 taxa) can be used to treat respiratory diseases. A significant number of species (56 taxa or $31.6 \%$ ) are used in official and folk medicine for the treatment of diseases of the cardiovascular and nervous system. 52 species (or $29.3 \%$ ), are used for the treatment of kidneys and urinary tract.

\section{Conclusion}

i) On the territory of the Atyrau region (the Western Kazakhstan), 177 species of medicinal plants belonging to 118 genera and 46 families were found. The largest number of medicinal plant species is noted in Asteraceae, Lamiaceae, Brassicaceae, Rosaceae, Chenopodiaceae, Fabaceae and Polygonaceae families, which include $48.3 \%$ of the total number of genera and $54.7 \%$ of the total number of species.

ii) The identified species of medicinal plants are ranked by the degree of spreading, which made it possible to distinguish 4 categories: a) The group of widespread, but growing sporadically, not forming thickets includes 128 species; b) The group of rare and endangered species that cannot be harvested for raw materials (11 species); c) Species forming small thickets amounted (23 taxa); d) Species that form significant thickets suitable for industrial harvesting (15 taxa).

iii) Among the medicinal plants of the Atyrau region, 6 ecological groups are identified in relation to humidification conditions: hydrophytes, hygrophytes, mesophytes, meso-xerophytes, xero-mesophytes and xerophytes. The largest number of species is noted to the xerophyte group (57 taxa).

iv) 8 groups of life forms are defined. The largest number of species is concentrated in the group of perennial herbaceous plants - 105 taxa, the last positions are occupied by a group of low shrubs ( 2 species) and low semi-shrubs (1 taxon).

v) The dominated number of species belongs to the wild species used in folk medicine -128 taxa; 49 species are used in official medicine. 12 pharmaceutical-therapeutic groups of plants for treatment of diseases of various etiologies are identified.

Thus, on the territory of the Atyrau region, a significant species composition of medicinal plants is discovered, covering almost the entire spectrum of pharmaceutical and therapeutic activity, which indicates a high prospect of their practical use. 


\section{Acknowledgements}

The article is prepared in accordance with Grant Project of Science Committee of the Ministry of Education and Science (AP092600081 «Study of biological features, ranges, raw materials of medicinal plants of Atyrau region and assessment of their practical use»).

\section{References}

1 Стратегия ВО3 в области народной медицины на 2014-2023 гг. [Электронный ресурс]. — Режим доступа: https://clinical-homeopathy.ru/wp-content/uploads/2020/06/strategy_2014_2023_rus.pdf

2 Kamazeri T. Antimicrobial activity and essential oils of Curcuma aeruginosa, Curcuma mangga, and Zingiber cassumunar from Malaysia / T. Kamazeri, A.S. Othman, M. Taher, D. Susanti, H. Qaralleh // Asian Pacific Journal of Tropical Medicine. 2012. - Vol. 5, No. 3. - P. 202-209.

3 Medical plant conservation. - Ontario, 2011. - Vol. 14. - $36 \mathrm{p}$.

4 Nature's pharmacy, our treasure chest: why we must conserve our natural heritage. A native plant conservation campaign report. - New-York, 2008. - 19 p.

5 WHO monographs on selected medicinal plants. - Ottawa: WHO, 2001. — Vol. 3. — 390 p.

6 Грудзинская Л.М. Аннотированный список лекарственных растений Казахстана: справ. / Л.М. Грудзинская, Н.Г. Гемеджиева, Н.В. Нелина, Ж.Ж. Каржаубекова. - Алматы, 2014. - 200 с.

7 Курбатова Н.В. Фитохимическое исследование болиголова пятнистого Cопium maculatum из предгорий Заилийского Алатау / Н.В. Курбатова, Н.Г. Гемеджиева, Л.С. Кожамжарова // Вестн. Караганд. ун-та. Сер. Биология. Медицина. География. - 2009. - № 3. - С. 29-32.

8 Бананова В.А. Атлас растений Северо-Западного Прикаспия / В.А. Бананова, В.Г. Лазарева. — Элиста: ЗАОр «НПП «Джангар», 2013. - 267 c.

9 Guidelines for the regulation of herbal medicines in the South-East Asia region. — New-Delhi: WHO, 2003. - $30 \mathrm{p}$.

10 Государственная фармакопея Республики Казахстан. - Астана; Алматы, 2008-2014. - Т. 1-3.

11 Мырзагалиева А.Б. Ресурсы лекарственных растений: моногр. / А.Б. Мырзагалиева. - Усть-Каменогорск: Изд-во ВКГУ им. С. Аманжолова, 2012. - 316 с.

12 Джаналиева К.М. Физическая география Республики Казахстан / К.М. Джаналиева, Т.И. Будникова, Е.Н. Веселов и др. - Алматы: Қазақ ун-ті, 1998. — 266 с.

13 Якубов Т.Ф. Песчаные пустыни и полупустыни Северного Прикаспия / Т.Ф. Якубов. - М., 1955. - 532 с.

14 Агроклиматические ресурсы Гурьевской и Мангышлакской областей Казахской ССР. — Л.: Гидрометеоиздат, 1978. $-107 \mathrm{c}$.

15 Фаизов К.Ш. Почвы Казахской ССР. Вып. 13. Гурьевская область / К.Ш. Фаизов. - Алма-Ата, 1970. — 350 с.

16 Лысенко В.В. Закономерности распределения растительности Атырауской области / В.В. Лысенко // Изв. НАН РК. Сер. биол. и мед. - 2010. - № 1. - С. 81-86.

17 Димеева Л.А. Динамика растительности пустынь Приаралья и Прикаспия: автореф. дис. ... д-ра биол. наук / Л.А. Димеева. - СПб., 2011. - 48 с.

18 Муратова Н.Р. Оценка состояния естественной растительности Прикаспийского региона в зависимости от погодных и ландшафтных особенностей / Н.Р. Муратова, С. Северская, А.Г. Терехов, Н.Т. Аманова, Н. Цычуева // Современные проблемы дистанционного зондирования Земли из космоса. - 2006. - Т. 3, № 2. - С. 351-358.

19 Мухамбетов М.Ж. Оценка процессов восстановления деградированных экосистем Атырауской области: дис. ... PhD / М.Ж. Мухамбетов. - Алматы, 2016. - 152 с.

20 Ишмуратова М.Ю. Изучение диких сородичей культурных растений Актюбинского флористического округа / М.Ю. Ишмуратова, А.А. Иманбаева, Г.Б. Копбаева // Вестн. КазНУ. Сер. экол. — 2016. — № 3 (48). — С. 49-58.

21 Czerepanov S.K. Vascular plants of Russia and adjacent states (the former USSR)/ S.K. Czerepanov. — Cambridge: University Press, 1995. - 516 p.

22 Флора Казахстана. - Алма-Ата: Изд-во АН КазССР, 1956-1966. - Т. 1-9.

23 Серебряков И.Г. Экологическая морфология растений. Жизненные формы покрытосеменных и хвойных / И.Г. Серебряков. - М.: Высш. шк., 1982. - 380 с.

24 Щербаков А.В. Полевое изучение флоры и гербаризация растений / А.В. Щербаков, А.В. Майоров. - М.: Изд-во МГУ, 2006. - $84 \mathrm{c}$.

25 Растительные ресурсы России. Дикорастущие цветковые растения, их компонентный состав и биологическая активность.- СПб.; М.: КМК, 2008-2012. - Т. 1-5.

26 Compendium of Medicinal and Aromatic Plants. Vol. II. Asia. - Triestre, 2006. - 295 p.

27 Журба О.В. Лекарственные, ядовитые и вредные растения / О.В. Журба, М.Я. Дмитриев. - М.: Колос, 2008. $512 \mathrm{c}$.

28 Suleimenov Ye.M. Composition of extract Eringium planum, obtained by $\mathrm{CO}_{2}$-extraction / Ye.M. Suleimenov, S. Machmudah, M. Sasaki, M. Goto // Chemistry of Natural Compounds. — 2010. — Vol. 46, Iss. 5. — P. 826-827. 


\title{
С.С. Сағындықова, А.А. Иманбаева, М.Ю. Ишмуратова, Г.Г. Гасанова
}

\section{Атырау облысының флорасынан дәрілік өсімдіктерді талдау}

\begin{abstract}
Дәрілік өсімдіктер аурудың алдын алу және емдеу үшін биологиялық белсенді заттар мен фитопрепараттардың маңызды көзі болып табылады. Қазақстанда Батыс Қазақстанның өңірлері жабайы дәрілік өсімдіктерге қатысты аз зерттелген. Осы зерттеудің мақсаты - Атырау облысы флорасының дәрілік өсімдіктерінің түрлік құрамына талдау жүргізу және оларды тіршілік формалары, экологиялық топтары, таралу дәрежесі және медициналық практикада қолдану мүмкіндігі бойынша саралау. Әдеби дереккөздерді талдау және жеке далалық зерттеулердің нәтижелері бойынша Атырау облысының аумағында 118 туысқа және 46 тұқымдасқа жататын дәрілік өсімдіктердің 177 түрінің өсетіні анықталды. Дәрілік өсімдіктердің ең көп саны Asteraceae, Lamiaceae, Brassicaceae, Rosaceae, Chenopodiaceae, Fabaceae және Polygonaceae тұқымдастарынан тұрады. Таралу дәрежесі бойынша өсімдіктер 4 топқа бөлінді: 1) кең таралған, бірақ сирек өсетін, қопалар түзбейтін (128 түр); 2) сирек кездесетін және жойылып бара жатқан, шикізатқа дайындалуға жатпайтын (11 түр); 3) шағын қопалар құрайтын (23 таксон); 4) өнеркәсіптік дайындауға жарамды едәуір қопалар құрайтын (15 таксон). Атырау облысының дәрілік өсімдіктерінің арасында ылғалдану жағдайларына қатысты 6 экологиялық топ бөлінді: гидрофиттер, гигрофиттер, мезофиттер, мезоксерофиттер, ксеросезофиттер және ксерофиттер. Өмір сүру формаларының 8 тобы анықталды. Түрлердің ең көп саны көпжылдық шөптесін өсімдіктер тобында шоғырланған - 105 таксон. Халықтық медицинада қолдану бойынша 128 таксон, ресми медицинада - 49 түрі бөлінді. Әр түрлі этиологияның ауруларын емдеу үшін өсімдіктердің 12 фармако-терапиялық топтары бөлінді.
\end{abstract}

Кілт сөздер: дәрілік өсімдік, Атырау облысы, жіктеу, тіршілік формалары, экологиялық топ, таралуы, фармакологиялық қасиеттері, халықтық және ресми медицинада қолданылуы.

\section{М.С. Сагындыкова, А.А. Иманбаева, М.Ю. Ишмуратова, Г.Г. Гасанова}

\section{Анализ флоры лекарственных растений Атырауской области}

\begin{abstract}
Лекарственные растения являются важными источниками биологически активных веществ и фитопрепаратов для профилактики и лечения заболеваний. В Казахстане регионы Западного Казахстана остаются мало изученными в отношении дикорастущих лекарственных растений. Цель настоящего исследования - провести анализ видового состава лекарственных растений флоры Атырауской области и их ранжирование по жизненным формам, экологическим группам, степени распространения и возможности применения в медицинской практике. По итогам анализа литературных источников и результатов собственных полевых исследований на территории Атырауской области выявлено произрастание 177 видов лекарственных растений, относящихся к 118 родам и 46 семействам. Наибольшое число видов лекарственных растений отмечено в семействах Asteraceae, Lamiaceae, Brassicaceae, Rosaceae, Chenopodiaceae, Fabaceae и Polygonaceae. По степени распространения выделены 4 группы растений: 1) широко распространенные, но растущие спорадично, не образующие зарослей (128 видов); 2) редкие и исчезающие, не подлежащие заготовке на сырье (11 видов); 3) образующие небольшие заросли (23 таксона); 4) образующие значительные заросли, пригодные для промышленной заготовки (15 таксонов). Среди лекарственных растений Атырауской области выделено 6 экологических групп по отношению к условиям увлажнения: гидрофиты, гигрофиты, мезофиты, мезоксерофиты, ксеросезофиты и ксерофиты. Определены 8 групп жизненных форм. Наибольшее число видов сосредоточено в группе многолетних травянистых растений - 105 таксонов. По использованию в народной медицине были выделены 128 таксонов, в официальной медицине - 49 видов. Обозначены 12 фармако-терапевтических групп растений для лечения заболеваний различной этиологии.
\end{abstract}

Ключевые слова: лекарственное растение, Атырауская область, систематика, жизненные формы, экологическая группа, распространение, фармакологические свойства, применение в народной и официальной медицине.

\section{References}

1 Stratehiia VOZ v oblasti narodnoi meditsiny na 2014-2023 hh. [WHO Strategy for Traditional Medicine on 2014-2023]. clinical-homeopathy.ru Retrieved from https://clinical-homeopathy.ru/wp-content/uploads/2020/06/strategy_2014_2023_rus.pdf [in Russian].

2 Kamazeri, T., Othman, A.S., Taher, M., Susanti, D., \& Qaralleh, H. (2012). Antimicrobial activity and essential oils of Curcuma aeruginosa, Curcuma mangga, and Zingiber cassumunar from Malaysia. Asian Pacific Journal of Tropical Medicine, 5(3), 202-209.

3 (2011). Medical plant conservation. Vol. 14. Ontario. 
4 Nature's pharmacy, our treasure chest: why we must conserve our natural heritage. A native plant conservation campaign report (2008). New-York.

5 WHO monographs on selected medicinal plants (2001). (Vol. 3). Ottawa: WHO.

6 Grudzinskaya, L.N., Gemedzhieva, N.G., Nelina, N.V., \& Karzhaubekova, Zh.Zh. (2014). Annotirovannyi spisok lekarstvennykh rastenii Kazakhstana [Annotated list of medicinal plants of Kazakhstan]. Almaty [in Russian].

7 Kurbatova, N.V., Gemedzhieva, N.G., \& Kozhamzharova, L.S. (2009). Fitokhimicheskoe issledovanie boliholova piatnistoho Conium maculatum iz predhorii Zailiiskoho Alatau [Phytochemical study of Conium maculatum from Transili Alatau]. Bulletin of the Karaganda University. Series Biology. Medicine. Geography, 3, 29-32 [in Russian].

8 Bananova, V.A., \& Lazareva, V.G. (2013). Atlas rastenii Severo-Zapadnoho Prikaspiia [Atlas of plants of the North-West Caspian]. Elista: «NPP «Dzhangar» [in Russian].

9 Guidelines for the regulation of herbal medicines in the South-East Asia region (2003). New-Delhi: WHO.

10 Hosudarstvennaia farmakopeia Respubliki Kazakhstan [The State Pharmacopeia of the Republic of Kazakhstan]. (20082014). (Vols. 1-3). Astana; Almaty [in Russian, in Kazakh].

11 Myrzagaliyeva, A.B. (2012). Resursy lekarstvennykh rastenii [Resources of medicinal plants]. Ust-Kamenogorsk: Publ. of EKSU named after S. Amanzholov [in Russian].

12 Dzhanaliyeva, K.M., Budnikova, T.I., \& Veselov, E.N. et al. (1998). Fizicheskaia heohrafiia Respubliki Kazakhstan [Physical geography of the Republic of Kazakhstan]. Almaty: Qazaq universiteti [in Russian].

13 Yakubov, T.F. (1955). Peschanye pustyni i polupustyni Severnoho Prikaspiia [Sand deserts and semi-deserts of the Northern Caspian region]. Moscow [in Russian].

14 Ahroklimaticheskie resursy Hurevskoi i Manhyshlakskoi oblastei Kazakhskoi SSR [Agro-climatic resources of Gur'ev and Mangyshlak regions of Kazakh SSR]. (1978). Leningrad: HydroMeteoIzdat [in Russian].

15 Faizov, K.Sh. (1970). Pochvy Kazakhskoi SSR. Vyp. 13. Hurevskaia oblast [The soil of Kazakhstan. Issue 13. Gur'ev region]. Alma-Ata [in Russian].

16 Lysenko, V.V. (2010). Zakonomernosti raspredeleniia rastitelnosti Atyrauskoi oblasti [Patterns of vegetation distribution of Atyrau region]. Izvestiia NAN RK. Seriia biolohicheskaia i meditsinskaia - Bulletin of National Academy of Science, series biological and medicinal, 1, 81-86 [in Russian].

17 Dimeyeva, L.A. (2011). Dinamika rastitelnosti pustyn Priaralia i Prikaspiia [Dynamics of vegetation of deserts of Aral and Caspian region]. Doctor's thesis. Saint Petersburg [in Russian].

18 Muratova, N.R., Severskaya, S., Terekhov, A.G., Amanova, N.T. \& Cychueva, N. (2006). Otsenka sostoianiia estestvennoi rastitelnosti Prikaspiiskoho rehiona v zavisimosti ot pohodnykh i landshaftnykh osobennostei [Assessment of natural vegetation state of the Caspian region depending on weather and landscape characteristics]. Sovremennye problemy distantsionnoho zondirovaniia Zemli iz kosmosa - The modern problems of distant zoning of the Earth from space, 3 (2), 351-358 [in Russian].

19 Mukhambetov, M.Zh. (2016). Otsenka protsessov vosstanovleniia dehradirovannykh ekosistem Atyrauskoi oblasti [Assessment of processes of restoration of degraded ecosystems of Atyrau region]. PhD thesis. Almaty [in Russian].

20 Ishmuratova, M.Yu., Imanbayeva, A.A., \& Kopbayeva, G.B. (2016). Izuchenie dikikh sorodichei kulturnykh rastenii Aktiubinskoho floristicheskoho okruha [Study of the wild relatives of cultivated plants of the Aktobe floristic region]. Vestnik Kazakhskoho natsionalnoho universiteta. Seriia ekolohicheskaia - Bulletin of KazNU. Series ecological, 3 (48), $49-58$ [in Russian].

21 Czerepanov, S.K. (1995). Vascular plants of Russia and adjacent states (the former USSR). Cambridge: University Press.

22 Flora Kazakhstana [Flora of Kazakhstan] (1964). (Vol. 7). Alma-Ata: Publ. of Academy of Science of KazSSR [in Russian].

23 Serebriakov, I.G. (1982). Ekolohicheskaia morfolohiia rastenii. Zhiznennye formy pokrytosemennykh i khvoinykh [Ecological morphology of plants. Life forms of angiosperm and coniferous]. Moscow: Vysshaia shkola [in Russian].

24 Shcherbakov, A.V., \& Maiorov, A.V. (2006). Polevoe izuchenie flory i herbarizatsiia rastenii [Field study and plant herbarization]. Moscow: MSU Publ. [in Russian].

25 Rastitelnye resursy Rossii. Dikorastushchie tsvetkovye rasteniia, ikh komponentnyi sostav i biolohicheskaia aktivnost [Plant resources of Russia. Wild flowering plants, their component compositions and biological activity]. (2008-2012). (Vol. 1-5). Saint Petersburg; Moscow: Publ. KMK [in Russian].

26 Compendium of Medicinal and Aromatic Plants. Vol. 2. Asia. (2006). Triestre.

27 Zhurba, O.V., \& Dmitriyev, M.Ya. (2008). Lekarstvennye, yadovitye $i$ vrednye rasteniia [Medicinal, venom and dangerous plants]. Moscow: Kolos [in Russian].

28 Suleimenov, Ye.M., Machmudah, S., Sasaki, M., \& Goto, M. (2010). Composition of extract Eringium planum, obtained by $\mathrm{CO}_{2}$-extraction. Chemistry of Natural Compounds, $46(5), 826-827$. 